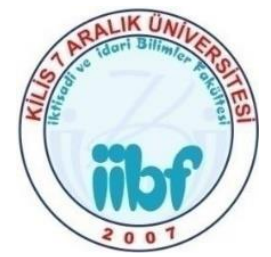

\title{
Devletlerarası İlişkilerde Kimlik: Mursi Dönemi Türkiye-Mısır İlişkileri ${ }^{1}$ Identity in Interstate Relations: Turkey-Egypt Relations in the Morsi Era
}

\section{Harun ÇELIKCAN ${ }^{2}$, Hakan CAVLAK ${ }^{3}$}

Öz

Amaç: Makalenin amacı, Muhammed Mursi İktidarı döneminde Mısır ile Türkiye arasında değișen ilişkileri iki devletin o dönem sahip olduğu kimlikleri üzerinden açıklayarak kimliğin devletlerarası ilişkileri inșa edici rolünü ortaya koymaktır.

Tasarım/Yöntem: Makale tasarımı, sosyal inşacı yaklaşımın varsayımları 1şığında ve devlet kimliklerinin dinamik ve değişken bir yapıda olduğu göz önüne alınarak bu dönemde iki devlet kimliğinin ne şekilde değiştiği ve değișen kimlikle beraber ilişkilerin nasıl yeni bir boyut kazandığı soruları üzerine inșa edilmiștir.

Sınırlılıklar: Türkiye-Mısır ilişkilerini incelerken makalenin odağ kimlik olmuştur, ilişkileri etkileyen diğer unsurlara araştırmanın kapsamını sınırlamak ve tasarımına sadık kalmak için bilinçli olarak değinilmemiştir.

Bulgular: Makalede, iki hükümetin birbirlerine yönelik algılarını ve politikalarını anlamak için iki tarafin kimlikleri ve kimliklerinin oluşum süreci incelenmiştir. Söz konusu dönemde Misır hükümetin olușturan Müslüman Kardeşler ile Türkiye hükümetini olușturan Adalet ve Kalkınma Partisi'nin başkanının ve kurucularının önemli bir kısmının etkilendiği Milli Görüş hareketinin fikirsel düzlemde birbirlerine benzedikleri görülmüştür.

Özgünlük/Değer: Türkiye-Mısır ilişkilerinin, Adalet ve Kalkınma Partisi ve Mursi döneminde iyileșmesinde ve siyasi kimliklerinin oluşumunda her iki hükümetin üyelerinin benzer bir ideolojik geçmișten gelmelerinin önemli bir faktör olduğu tespit edilmiștir. Sahip oldukları ortak kimliğin hükümetleri aracılığı ile devletleri etkilediği ve bunun sayesinde de kolaylıkla ortak bir dil geliştirebildikleri ve çıkarlarını ortaklaştırabildikleri iddia edilmiștir. Diğer bir deyişle, ortak veya benzer kimliğe sahip hükümetlerin, devletlerarası ilişkileri geliştirdiği öne sürülmüştür.

Anahtar Kelimeler: Türkiye-Mısır İliskileri, Sosya Konstrüktivizm, Kimlik, Müslüman Kardeşler, Millî Görüş Hareketi

\section{Abstract}

Purpose: The objective of this paper is to present the constructive role of identity by explaining the changing relationship between Egypt and Turkey by focusing on their identities during the period in question.

Design/Methodology: The paper design has been constructed in line with the premises of social constructivism, upon the questions of to what extent the state identities of both countries have been changed and how the relations gained a new dimension following the change in the two states' identities.

Limitations: The focus of the paper is deliberately limited to the issue of identity to limit the scope of the paper and to be loyal to the paper design, although there might be other factors affecting the relations.

Findings: To comprehend the perceptions and policies of both governments vis-à-vis each other, their identities and identity formation processes are analyzed. Accordingly, it is observed that there are various similarities in the ideologies of the Muslim Brotherhood, which then constituted the government of Egypt, and the National Outlook Movement, which had inspired the leader and founders of the Justice and Development Party.

Originality/Value: The strengthening of Turkey-Egypt relations in the era of Morsi and Justice and Development Party is entailed from their similar ideological past which had been an integral factor that had shaped their political identities. Thus, the paper argues that similar identities affect the states through the governments, which in turn opens the way to develop a common understanding and a common interest-formation between the states. In other words, interstate relations improve among governments who have similar identities.

Keywords: Turkey-Egypt Relations, Social Constructivism, Identity, Muslim Brothers, The National Outlook Movement

\footnotetext{
${ }^{1} \mathrm{Bu}$ makale Harun Çelikcan'ın Doç. Dr. Hakan Cavlak danışmanlığında yazdığı "Uluslararası İlişkilerde Kimlik: Mursi Dönemi Mısır- Türkiye İlişkileri” isimli yüksek lisans tezinden türetilmiștir.

${ }^{2}$ Uzman, Tekirdağ Namık Kemal Üniversitesi, Sosyal Bilimler Enstitüsü, harune181 @ gmail.com, ORCID: 0000-0003-38573034

3 Doç. Dr.,Tekirdağ Namık Kemal Üniversitesi, İktisadi İdari Bilimler Fakültesi, Uluslararası İlişkiler Bölümü, hakancavlak@gmail.com, ORCID: 0000-0003-1119-9900
} 


\section{GİRIŞ}

Arap Baharı sürecinde Müslüman Kardeşlerin Mısır'da iktidara gelmesinin Türkiye ile Mısır ilişkilerine önemli bir yansıması olmuştur. Müslüman Kardeşlerin iktidarda bulunduğu süre içerisinde Türkiye-Mısır ilişkileri önemli bir şekilde iyileşme göstermiş ve önceki dönemlere göre farklı bir boyuta geçmiştir. Bunun öncesinde, iki devlet arasında kuruldukları tarihten beri istikrarlı bir ilişki sürdürülememiş ve ilişkiler uzun bir süre boyunca düşük bir düzeyde seyretmiştir. Genellikle rekabet ve krizlerin gölgesinde seyreden ilişkilerin bu dönemde kısa bir süre içerisinde hızlı bir şekilde değişerek altın çağını yaşaması, söz konusu Mursi dönemi boyunca ikili ilişkilerin ilgi çekici ve araştırılmaya değer olduğunu göstermektedir. Bu dönemde iki devletin birbirlerine yönelik değişen bakış açısı ve bunun sonucunda kurulan ikili ilişkiler, aynı süreç içerisinde benzer iktidar anlayışlarına sahip olmalarından kaynaklanmaktadır.

Türkiye ve Mısır ortak bir tarihsel geçmişe sahip olmalarına rağmen, ilişkileri kuruluşlarından itibaren rekabet ve krizlerin gölgesinde seyretmiştir. Uzun yıllar mesafeli sürdürülen ilişkiler, Arap Baharı sürecinde Mısır'da Muhammed Mursi ile Müslüman Kardeşlerin iktidar olması ile hızla değişmeye başlamış ve ikili ilişkilerin altın çağ 1 olarak kabul edilebilecek bir döneme girilmiştir. Makalenin amacı, Muhammed Mursi iktidarı döneminde Mısır ile Türkiye arasında değişen ilişkileri iki devletin o dönem sahip oldukları kimlikler üzerinden açıklayarak kimliğin devletlerarası ilişkileri inşa edici rolünü ortaya koymaktır. Makale tasarımı, sosyal inşacı yaklaşımın varsayımları ışığında ve devlet kimliklerinin dinamik ve değişken bir yapıda olduğu göz önüne alınarak bu dönemde iki devletin kimliklerinin ne şekilde değiştiği ve değişen kimlikle beraber ilişkilerin nasıl yeni bir boyut kazandığı soruları üzerine inşa edilmiştir. Türkiye-Mısır ilişkilerini incelerken makalenin odağını kimlik oluştururken, ilişkileri etkileyen diğer unsurlara araştırmanın kapsamını sınırlamak ve tasarımına sadık kalmak için bilinçli olarak değinilmemiştir. Makalede, iki hükümetin birbirlerine yönelik algılarını ve politikalarını anlamak için iki tarafın kimlikleri ve kimliklerinin oluşum süreçleri incelenmiştir. Söz konusu dönemde Mısır hükümetini oluşturan Müslüman Kardeşler ile Türkiye hükümetini oluşturan Adalet ve Kalkınma Partisi'nin genel başkanının ve kurucularının önemli bir kısmının etkilendiği Milli Görüş hareketinin fikirsel düzlemde birbirlerine benzedikleri görülmüştür. Türkiye-Mısır ilişkilerinin, Adalet ve Kalkınma Partisi ve Mursi döneminde iyileşmesinde ve siyasi kimliklerinin oluşumunda, her iki hükümetin üyelerinin benzer bir ideolojik geçmişten gelmelerinin önemli bir faktör olduğu tespit edilmiştir. Sahip oldukları ortak kimliğin hükümetleri aracıllğı ile devletleri etkilediği ve bunun sayesinde de kolaylıkla ortak bir dil geliştirebildikleri ve çıkarlarını ortaklaştırabildikleri iddia edilmiştir. Diğer bir deyişle, ortak veya benzer kimliğe sahip hükümetlerin, devletlerarası ilişkilerinin de iyileştiği öne sürülmüştür.

Türkiye ile Mısır ilişkileri de birçok farklı bakış açısı ile ele alınarak açıklanabilecek bir yapıya sahip olsa da bu çalışmada iki devletin kimlik yapılarının ilişkilerin inşa edilmesindeki etkisi değerlendirilecektir. Kimliğin devletlerarası ilişkilerin inşa edilmesindeki rolünün Mursi dönemi Mısır-Türkiye ilişkileri örneği ile açıklanması makalenin konusunu oluşturmaktadır. Benzer kimliklere sahip siyasal iktidarlar tarafindan yönetilen devletler arasındaki ilişkilerin geliştiği iddiası, bu makalenin temel argümanını oluşturmaktadır.

Devletler birbirleri ile sürekli bir etkileşim içerisindedirler. Bu ilişkiler ise sürekli değişerek ve dönüşerek zaman zaman farklı biçimlere evrilmektedir. Devletler arası ilişkilerde yaşanan bu değişim ve dönüşümler ana problem olarak araştırılacaktır.

Araştırmanın ana hipotezi, değişen koşullar ve uygun şartların ortaya çıkması ile iki devletin uyumlu halen gelen kimlik yapılarının ilişkilerde ana etkileyici unsur olduğudur. Mursi döneminde Mısır ile Türkiye arasında iyi ilişkilerin kurulması, o dönemde iki devletin iktidar yapılarının birbirlerine benzer anlayışlara sahip olması ve kimliklerinin birbirleri ile uyumlu olmasından kaynaklanmaktadır.

Makalenin amacı, Muhammed Mursi İktidarı döneminde Mısır ile Türkiye arasında değişen ilişkileri iki devletin o dönem sahip olduğu kimlikleri üzerinden açıklayarak kimliğin devletlerarası ilişkileri inşa edici rolünü ortaya koymaktır. Sosyal inşacı yaklaşımın varsayımları 1şığında ve devlet kimliklerinin dinamik ve değişken bir yapıda olduğu göz önüne alınarak bu dönemde iki devlet 
kimliğinin ne şekilde değiştiği ve değişen kimlikle beraber ilişkilerin nasıl yeni bir boyut kazandığ1 açıklanacaktır.

Devletler arası ilişkiler açıklanırken, genellikle gözden kaçırılan noktalardan biri, devletlerin de birer sosyal varlık oldukları ve birbirleri ile girdikleri ilişkilerin de sosyal olarak inşa edildiğidir. Devlet davranışlarını sadece materyal yapılar üzerinden açıklamak sınırlı ve açıklayıcı yönü eksik olan bir bakış açısını yansıtmaktadır. Sosyal yapılar da devlet davranışlarının şekillenmesinde en az maddi yapılar kadar etkili olmaktadırlar. Sosyal bir inşa sonucunda ortaya çıkan kimlik, devletlerin çıkar belirlemelerinde ve politika oluşturmalarında etkili olmaktadır. Mursi dönemi Mısır ile Türkiye arasında gerçekleşen ilişkiler ele alınarak, kimliğin, ilişkilerin inşa edilmesindeki rolü ortaya konulacak ve kimliğin önemine dikkat çekilecektir.

\section{SOSYAL INSŞACILIK}

Uluslararası İlişkiler disiplini gelişim süreci içerisinde farklı yaklaşımlar arasında tartışmalara sahne olmuştur. "Büyük tartışmalar" olarak adlandırılan bu tartışmalar, yaklaşımların birbirlerine yönelttiği eleştiriler çerçevesinde yaşanmaktadır ve disiplinin tarihi bu tartışmalar çerçevesinde yazılmaktadır (Küçük, 2014: 46). Sosyal inşacı yaklaşımının disiplin içerisindeki rolünü ve konumunu anlama adına bu tartışmalara temel çerçevede kısaca değinmek faydalı olacaktır.

Yaşanan bu tartışmalar genelde üç ana eksende ele alınmaktadır. Bu tartışmaların ilki; Birinci Dünya Savaşı sonrasında 1940'lı yıllarda idealizm ile realizm arasında yaşanmış ve savaşın yarattığı yıkım sonrasında uluslararası barışın nasıl sağlanacağı çerçevesinde çalışmalar geliştirilmiştir (Arı, 2010: 40). Bu tartışmada realizmin, insanın doğası gereği kötü olduğundan hareketle uluslararası politikayı bir güç mücadelesi çerçevesinde değerlendirmesiyle idealizme galip geldiği varsayılmaktadır (Kaya, 2008: 87). 1960'lı yıllarda birinci tartışmadan galip çıkan realizme, davranışsalcılar tarafından yöneltilen eleştiriler, gelenekselci - davranışsalcı tartışması olarak bilinen ikinci büyük tartışmayı meydana getirmiştir. Bu tartışmanın genel konusu, tarihsel ve bilimsel açıklama yöntemlerinin birbirinden farklı olduğu ve uluslararası ilişkiler teorilerinin nasıl bir bilimsel temele oturtulması gerektiği çerçevesinde gerçekleşmiştir. Bu tartışmada doğa bilimleri gibi sosyal bilimlere de deneysel yöntemlerle yaklaşılması gerektiğini varsayan pozitivizm disiplinin hâkim metodolojisi haline gelmiştir (Küçük, 2014: 47). Disiplin içerisindeki üçüncü büyük tartışma 1980'li yıllarda ortaya çıkmış pozitivizm ile post-pozitivizm arasındaki metodolojik ve epistemolojik temelli tartışmadır (Kaya, 2008: 7). Pozitivizmin, bilimi, sistemi açıklamada tek geçerli yöntem olarak görmesi eleştirilmiş, sistemde gerçekleşen olayları açıklamakta sosyal olgularında rol alması gerektiği post-pozitivistler tarafindan öne sürülmüştür (Ar1, 2010: 49). Hem pozitivist epistemolojiye hem de rasyonelliğe ciddi eleştiriler yöneltilmesi ile disiplin içerisindeki kuramsal ayrılık belirginleşmiştir (Ateş, 2008: 215). Genel olarak literatüre bakıldığında sosyal inşacı yaklaşımın bu üçüncü büyük tartışma içerisinden meydana geldiği kabul edilmektedir.

Uluslararası ilişkiler disiplininde yaşanan bu üçüncü büyük tartışma sonucunda ve Soğuk Savaş'ın bittiği 1990'lı yılların başlarında, kuramsal altyapısı Nicholas Onuf tarafindan hazırlanan sosyal inşacılık, Alexander Wendt tarafından mevcut kuramsal açıklamalara bir alternatif yaklaşım olarak geliştirilerek literatüre girmiştir (Kiraz, 2014: 211). Sosyal inşacılık, aslında bir uluslararası ilişkiler yaklaşımı değildir. 1990'lı yıllardan itibaren Alexander Wendt'in yaptığı çalışmalar ile uluslararası ilişkiler disiplinine girmiş ve bu alanda en temel kuramlardan biri haline gelmiştir. $\mathrm{Bu}$ dönemde disiplin içerisinde öne çıkmaya başlayan sosyal inşacıllk, uluslararası ilişkiler alanını anlamaya yönelik farklı çerçeveler önermeye başlamıştır. Uluslararası ilişkiler yaklaşımlarının temel tartışma konuları olan; anarşi, güç dengesi, çıkar ve devlet kimliği arasındaki ilişki, devletler arası iş birliğinin veya çatışmaların açıklanması anlamında alternatif açıklamalar geliştirmiştir (Akpınar, 2015: 9). Sosyal inşacı yaklaşım, rasyonalist teorilere ciddi eleştiriler yönelterek ve Soğuk Savaş sonrası kurulan yeni düzene farklı bakış açıları getirerek literatürde yer edinmiştir.

Pozitivist yaklaşımlar, devletler arasındaki etkileşimleri ve bu etkileşimlerin sonuçlarını güç ve benzeri maddi öğeler ile açıklarken, sosyal inşacı yaklaşım, toplumsal gerçekliğin bir sosyal inşa sonucu var olduğunu ve uluslararası ilişkilerinde bir sosyal gerçeklik olarak devletlerin sosyal olarak birbirlerini etkilemesi sonucunda inşa edildiğini iddia etmektedir (Küçük, 2014: 325). Sosyal inşacı yaklaşımın uluslararası ilişkileri sosyal bir alan olarak görmesi ve gerçekleşen olayları sosyal 
etkileşimlerin bir sonucu olarak kabul etmesi, disiplin içerisinde iddialı bir konuma gelmesini sağlamıştır.

Uluslararası ilişkilerde sistemin şekillenmesinin, güç dağılımı ile değil de, sistem içerisinde bulunan aktörlerin taşıdıkları fikir, algı ve düşüncelerle şekillendiğini savunan sosyal inşacılık, disiplin içerisinde kendine farklı bir pozisyon belirleyerek ortaya çıkmıştır (Yılmaz, 2013: 161). Rasyonalist uluslararası ilişkiler yaklaşımlarının üzerinde durduğu güç ve çıkar temelli bir yapının mevcudiyetini tamamen yok saymamakla beraber, kimlik ve fikirlerin ne şekilde oluştuğu ve bunların devletlerin politikalarına ne şekilde etki ettiği, kimlik, fikir ve algı gibi sosyal olguların aktör davranışlarını anlamakta nasıl bir role sahip olduğu üzerine odaklanmaktadır (Kaya, 2008: 63). Maddi yapıların yanında normatif yapıları da disipline dâhil ederek disiplinin düşünsel çerçevesini genişletmektedir.

Ontolojik temeline bakıldığında ise, sosyal inşacı yaklaşımın inceleme konusunun temelde insan bilinci ve bunun uluslararası ilişkilerdeki yerini incelemek olduğu görülmektedir. Rasyonalist yaklaşımların doğal ve verili olarak ele aldığı egemenlik, anarşi, güvenlik, çıkar gibi kavramlar sosyal bir inşa sonucunda ortaya çıkmış sosyal olgulardır (Küçük, 2014: 326). Nicholas Onuf'un, uluslararası ilişkilerin, insan davranışları temelinde inşa edildiği biçimindeki yargısını destekleyen Alexander Wendt (2012: 15), uluslararası siyasal yapının oluşumunda düşünce ve fikirlerin maddi yapılardan daha çok rol oynadığını iddia etmektedir. Wendt'e göre sosyal ve normatif yapılar da en az maddi yapılar kadar nesnel ve gerçektir.

Kimlik olgusu, sosyal inşacılıkta çok önemli bir yerde konumlanmaktadır. Kimlik, kendi varlığımızın farkına varmamızı sağlar ve bu bilinç ile siyasi ortamda kendimize göre bir konum belirlememizde etkili olur (Hoffman, 2010: 3). Aktörler ve yapılar siyasi sistem içerisindeki yerlerini taşıdıkları veya sahip olduklarını düşündükleri değerlere göre belirlemektedirler. Aynı zamanda, hangi yapı veya aktör ile ne tür bir ilişki kurmaları gerektiğini, benimsedikleri ya da karşıt oldukları değer yargılarına göre seçmektedirler

Christian Reus-Smit, aktörler tarafından paylaşılan fikir, değer, inanç ve normların yapısal özellikler göstermeleri sebebi ile aktörlerin sosyal ve siyasal alandaki davranış ve tutumları üzerinde belirleyici olduğunu vurgulamaktadır. Bu sebeple maddi yapılar bu aktörlerin paylaştıkları değer ve fikirler sayesinde önem kazanmaktadır. Aynı zamanda aktörlerin kimlik ve benlikleri de paylaşılan bu değerler tarafından şekillendirilir veya yaratılır (Reus-Smit, 2014: 294). Fikirler, inançlar ve değerler bu yapıcı özellikleri barındırmaları sebebi ile yaklaşımın üzerinde durduğu temel olgulardır.

\subsection{Kimlik Oluşumu ve İkili İlişskilerde Kimliğin Rolü}

Kimlik kavramı eleştirel yaklaşımların uluslararası ilişkiler disiplinine girmeleri ile beraber çok tartışılan ve üzerinde çok durulan bir kavram haline gelmeye başlamıştır. Disiplin içerisinde uzun süre geleneksel yaklaşımların güç, çıkar ve benzeri maddi öğeler temelinde tartışıp gündem dışı bıraktığı sosyal ve normatif değerlerin eleştirel teoriler tarafından tartışmaya açılması ile kimliğin önemi de artmaya başlamış ve temel tartışma konularından biri olmuştur.

Sosyal inşacı yaklaşım, kimlik kavramı üzerinde en çok duran ve disiplin içerisinde açıklayıcı rolüne en çok vurgu yapan yaklaşımdır. "Kimlik, bir şeyi olduğu şey yapan her ne ise odur" diyerek kimliği kısaca tanımlayan Wendt'e göre, bir aktörün kendisini tanımlayan öznel yapısı onun kimliğini tanımlamaktadır, ama bu aynı zamanda diğer aktörlerin bu aktörün o öznel yapısını o şekilde kabul edip etmediğine de bağlıdır. Bu durumda kimliğin oluşumu hem iç hem de dış faktör olmak üzere iki düşünce tarafından gerçekleştirilmektedir. $\mathrm{Bu}$ faktörler aktörün kendi benliğine ait düşünceler ve ötekine ait düşüncelerdir (Wendt, 2012: 279). Wendt'in yaklaşımına göre kimlik olgusunun belirlenebilmesi için iki taraflı bir kabulün olması gerekmektedir.

Wendt'e göre, kişiler kendilerini diğerlerinden farklı kılan tecrübeleri sonucunda kendilerine özel değerler oluşturur. Kimlik ise oluşturulan bu değerler sonucunda meydana gelir ve bir süreç olarak sürekli inşa edilir. Uluslararası politikalar ise böylelikle değer, norm ve çıkarlar tarafindan meydana gelen kimlik tarafindan şekillenir (Wendt, 2012: 280). Norm ve değerlerin kimlikleri oluşturabilmesi için üç temel mekanizmaya ihtiyaç vardır. Bunlar; tahayyül, iletişim ve baskıdır (Reus-Smit, 2014: 296). Burada dikkat edilmesi gereken şey, öncelikle kimliğin meydana gelmesinde öznel değerlerin varlığı ve oluşum aşamasında kimi araç ve şartların gerekliliğidir. 
Reus-Smite'e (2014: 296) göre kurumsallaşmış değer ve normlar aktörün kimliğini belirlerken aynı zamanda bu kimliğe sahip olan aktörün siyasi, iktisadi ve kültürel eylemlerinin ne şekilde gerçekleşeceğinin de arka planını oluşturmaktadır. Wendt (2012: 81), uluslararası politikada herhangi bir davranışı analiz ederken o davranışı şekillendiren sosyal yapının dikkate alınması gerektiğini düşünmektedir. Sosyal değer ve normlar sosyal yapı için düzenleyici rollere sahip olmaktadır.

Kimlik olgusu, sosyal inşacılıkta çok önemli bir yerde konumlanmaktadır, kimlik, kendi varlığımızın farkına varmamızı sağlar ve bu bilinç ile siyasi ortamda kendimize göre bir konum belirlememizde etkili olur (Hoffman, 2010: 3). Aktörler ve yapılar siyasi sistem içerisindeki yerlerini taşıdıkları veya sahip olduklarını düşündükleri değerlere göre belirlemektedirler. Aynı zamanda hangi yapı veya aktör ile ne tür bir ilişki kurmaları gerektiğini benimsedikleri ya da karşıt oldukları değer yargılarına göre seçmektedirler.

Oluşum şekli itibari ile karşılıklı etkileşim sonucunda meydana gelen kimlikler, aktörler arasındaki benzerliklere işaret ettiği gibi, aynı zamanda farklılıklara da işaret etmektedir. $\mathrm{Bu}$ da kimliğin "ben" ve "öteki" arasındaki etkileşimin bir sonucu olduğunu göstermektedir. Yani kimliklendirme hem olumlu hem de olumsuz olabilmektedir. Olumlu olduğu zaman politika yapımı esnasında diğerinin kazanımı ve refahı da göz önüne alınırken, olumsuz olduğu zaman ise, ötekinin refahı göz önüne alınmaksızın politika yapılır ve ötekinin hassasiyetleri bir araç olarak manipüle edilebilmektedir (Kaya, 2009: 104). Burada aktörlerin birbirlerini algılama şekilleri politika yapımında önemli rol oynamaktadır.

Wendt'e göre her aktör birden fazla kimliğe sahiptir ve sahip olduğu her kimlik türü aktörün davranışlarını şekillendirmede bir misyona sahiptir. Aktörlerin sahip olduğu kimlik sonucunda belirlenen ilgileri de karşılaştıkları duruma göre birbirlerine baskın gelebilmektedirler. Burada tehdit unsuru önemli bir etkendir. Hangi kimlik daha çok tehdit altındaysa diğer kimlikleri ikinci plana itmektedir (Wendt, 2012: 287). Örneğin bir devletin iç ve dış davranışlarını şekillendiren iç ve dış kimliklerinin olduğu varsayılırsa, devlet dış politikada herhangi bir tehdit algıladığında iç kimliğinin gerektirdiği ilgileri geri plana iterek dış ilgileri üzerine daha çok yoğunlaşabilir.

Wendt'e (2012: 78) göre düşünceler maddi nedenlere sahiptirler, ama maddi gücün anlamı ve çıkarın belirlenmesi düşünceler tarafindan gerçekleştirilir; aktörler arasındaki sosyal bağlar düşünceler tarafından oluşturulup organize edici bir role sahip olmaktadırlar ve maddi gücü birbirlerine karşı ne şekilde kullanılması gerektiği aşamasında organize ederler. Sosyal inşacı yaklaşım iki ana önermeyi temel alır. Birincisi, insanlar tarafından sosyal olarak birliktelikler oluşturulmaktadır ve bu birliktelikler maddi unsurlarla değil paylaşılan düşüncelerle kurulur. İkincisi, amaçlı aktörler olarak kabul edilen devletler de kimlik ve çıkarlarını esas olarak insanların paylaştığı bu düşünceler ile şekillendirmektedir (Özev, 2013: 486). İki ayrı toplumun sahip olduğu düşünsel benzerlikler onları temsil eden devletlerin iş birliği kurmasını kolaylaştırırken, aynı zamanda sahip oldukları düşünsel farklılıklar ise devletlerin iş birliğini zorlaştırmaktadır.

Toparlamak gerekirse, sosyal inşacı yaklaşım, devlet ilişkilerinin sahip olduğu kimlik çerçevesinde değişebileceğini öne sürmektedir. Ortak veya benzer bir kimliğe sahip olan devletler uluslararası alanda iyi ilişkiler kurarak hareket edebilmektedirler. Çalışmanın bir sonraki bölümünde Mursi dönemi Türkiye ile Mısır arasındaki ilişkileri açıklamak için iki devletin kimlik ve sosyal değerler çerçevesinde ilişki kurmalarında etkili olan Müslüman Kardeşler ve Millî Görüş hareketi ele alınacaktır. İki hareketin ideolojileri, düşünsel temelleri ve siyasi bakış açıları incelenerek bunlar arasındaki ortaklık ve benzerlikler ön plana çıkartılacak ve bunların ortak kimlik oluşumuna ne şekilde kaynaklık ettiği açıklanacaktır.

\section{MÜSLÜMAN KARDEŞLER VE MILLLİ GÖRÜŞ HAREKETİ}

Birinci Dünya Savaşı'ndan sonra Osmanlı Devleti'nin kontrolünden çıan Orta Doğu bölgesinde İngiltere ve Fransa'nın manda yönetimleri ile kurulan devletler bölgede istikrarı sağlayamamış ve yönetim şekilleri ile istikrarsızlığı daha da derinleştirmişlerdir (Pınar, 2015: 140). Aynı dönemde Mısır'da da uygulanan politikalardan huzursuzluk duyan geniş halk kesimleri ekonomik sorunlarına çözüm bulmak, inanç ve geleneklerini yeniden toplumda hâkim konuma getirmek için siyasal partilerden farklı işleyecek olan örgütlenmeler kurmaya başlamışlardı (Cleveland, 2014: 224). Bu örgütlenmelerden biri olan ve daha sonra Misır siyasal hayatına önemli 
ölçüde etki edecek olan Müslüman Kardeşler (Arapçasıyla, Ihvan-ı Müslimin) hareketi 1928 yılında Hasan El-Benna tarafından İsmailiye kentinde kuruldu (Ar1, 2004: 193).

Diğer yandan, Millî Görüş hareketi ise, Türkiye'de İslam dininin 1slahatçı bir görüşle politika içerisinde yer alması ve bu dinin gereklerine göre bir politik düzen oluşturulması amacı ile Necmettin Erbakan tarafından kurulmuş bir harekettir. Türkiye Cumhuriyeti'nin laik bir düzene yönelişinden sonra yönetim ve politikanın dışında kalan inanç faktörünün tekrardan siyasi alana dahil edilmek istenmesi Millî Görüş hareketinin önemli çıkış noktalarından biridir (Tuğrul, 2017: 617, 652). Millî Görüş hareketi, ilk kez 26 Ocak 1970 tarihinde kurulan Milli Nizam Partisi ile politik program ve hedeflerini açıklayarak siyasi alana açı biçimde dahil olmuştur (Manaz, 2008: 256). Böylece Milli Nizam Partisi, Millî Görüş düşüncesinin ilk siyasi yansıması olarak ortaya çıkmıştır.

Arap kimliği ve Müslüman kimliğini birbirleri ile özdeşleştirerek Arap dünyasının birçok bölgesinde faaliyet yürüten Müslüman Kardeşler, Müslüman toplumun bir kesiminde yaşanan bir sorunu bütün Müslümanların sorunu olarak görmekte ve bu anlamda bütünleyici bir nitelik taşımaktadır (Pargeter, 2010: 13). Toplumda inanç değerlerini hâkim kılmanın yanında sosyal reform önerileri ve sosyal adalet çağrısında bulunması aynı zamanda örgütün çağın gereklerine uygun modern bir yanının olduğunu göstermektedir (Cleveland, 2004: 224). Burada özellikle Müslüman ve Arap dünyasının sorunlarına yönelik çalışma yapması Müslüman Kardeşler'in bir anlamda kimlik temelli bir siyaset ve mücadele yöntemine sahip olduğunu göstermektedir.

Millî Görüş hareketinin kendisine biçtiği İslamcı kimlik ve büründügü rol, Batı'yı kendisinden farklı olarak görüp dışlamasına yol açmaktadır. Kendisini ve referans aldığı İslam inancını hakkın ve adaletin temsilcisi olarak görürken, Batılı devletleri adaletsizlik ve sömürünün temsilcileri olarak görmektedir (Kaya, 2017: 623). İslam medeniyetinin asırlar boyunca dünya barışına hizmet ettiğini öne süren Erbakan'a (2017: 34) göre İslam medeniyetlerinin maddi olarak güç kaybetmesi ile Batılı sömürgeci güçler İslam inancının tesis ettiği barışı bozarak bütün dünyaya adaletsizlik ve eşitsizlik getirmişlerdir. Bu sebeple Müslüman bir ülkenin Amerika Birleşik Devletleri (ABD) ve İsrail gibi devletlerle stratejik ortaklık kurmasını İslam inancına değil, bu ülkelerin amaçlarına hizmet etmek olarak görmektedir Burada Millî Görüş hareketinin dış politika anlayışında kimlik faktörünün önemli bir etken olduğu görülmektedir.

Müslüman Kardeşler'de olduğu gibi Millî Görüş hareketi de kendisini inanç temelli bir konuma oturtarak, sahip olduğu inanç ve değerler çerçevesinde bir kimlik belirlenimi yapmaktadır. Siyasal mücadelesini ise kimliğini dikkate alarak yürütmektedir. Yukarıda da değinildiği gibi Wendt'e göre, kişiler kendilerini diğerlerinden farklı kılan tecrübeleri sonucunda kendilerine özel değerler oluşturur. Kimlik ise oluşturulan bu değerler sonucunda meydana gelir ve bir süreç olarak sürekli inşa edilir. Uluslararası politikalar ise böylelikle değer, norm ve çıkarlar tarafından meydana gelen kimlik tarafından şekillenir (Wendt, 2012: 280). Burada sosyal inşacı yaklaşımının öne sürdüğü kimlik temelli siyaset yapma durumunu hem Müslüman Kardeşler hem de Millî Görüş hareketi somut olarak ortaya koymaktadır.

Hasan El-Benna, sosyal düzenin istikrarsızlaşmasını Mısır'daki İngiliz varlığına bağlayarak, sosyal düzenin sağlanmasında İslam inancının inşa edici bir role sahip olduğunu öne sürmüş ve İslam inancını toplum içerisinde ön plana çıkarmaya çalışmıştır (Levy, 2014: 147). İslam dünyasında eşitlik ve adalet temelli refah toplumu amaçlayan Müslüman Kardeşler, Batılı devletlerin dayattığ 1 demokrasi ve insan hakları gibi değerlerin İslam inancının süzgecinden geçirilerek uygulanması gerektiğini öne sürmüş, aksi halde bu değerlerin kendileri için yozlaştırıcı bir nitelik taşıyacağını vurgulamıştır (Benna, 2019: 130). Müslüman Kardeşler ideal bir toplum ve yönetim sistemi yaratmak için dönemin modern olarak kabul edilen değerlerinin İslam değerleri ile uyumlu hale getirilmesi gerektiğine inanmaktadır.

Diğer yandan, Millî Görüş hareketi'nin kurucusu Necmettin Erbakan ise, Batılı ülkeleri ve kurdukları düzeni hedef alarak, bu düzenin İslam dünyası için yıkıcı bir düzen işlevi gördügünü öne sürmüştür. Erbakan'a (2017: 217) göre, İslam dünyasında, Batının düzenine karşı İ̀lam inancına dayalı yeni bir düzen kurmak önemli bir gerekliliktir. Millî Görüş hareketine göre, Türkiye'yi batıya bağımlı olmaktan kurtarmak için başvurulması gereken en önemli seçenek toplumsal olarak milli bir şuura ulaşıp sahip olunan manevi değerleri canlandırmaktır (Yılmaz, 2016: 1167). Burada da 
görüldüğü gibi Millî Görüş hareketinin ideolojisinde Bat1 karşıtllı̆ğ tıpk1 Müslüman Kardeşler'de olduğu gibi önemli bir faktördür.

Müslüman Kardeşler, örgüt olarak kendisini Batılı devletlerin ülkede yaydığı seküler ideolojiye karşı kendi toplumunun sahip olduğu yerel inanç ve kültürün koruyucusu olarak konumlandırmaktadır (Pargeter, 2010: 18). Hasan El-Benna'ya göre, ortaya çıktıkları dönemde Mısır'ın toplumsal hayattan yönetime kadar bütün kontrolü yabancı güçlerin elindeydi. Misır halkı bu yabancı yönetimlerle sürekli bir savaş halindeydi ve bağımsızlık için mücadele vermekteydi. Genel olarak ülkede bir kargaşa hakimdi ve Müslüman Kardeşler bu kargaşanın içine doğrudan atılarak halkı doğru mücadele konusunda eğiterek onlara İslam şuuru ile hareket etmeyi öğretmekteydi (Benna, 2019: 260). Müslüman Kardeşler ilk dönemlerinde toplum sorunlarına müdahale şekli olarak bir çatışma veya doğrudan savaşa girmekten çok topluma İslam inancının değerlerini hatırlatarak, toplumu eğitme ve yönlendirmeye çalışmıştır.

Erbakan'a göre ise, İslam'ın bireysel düzeye indirgenerek sadece insan ile Allah arasındaki bir bağ olarak görülmesi yanlış ve emperyalistlerin amaçlarına hizmet eden bir tanımlamadır. İslam inancının sekülerleşmesi İslam dünyasında birlik olma bilincini ve duygusunu engellemektedir (Tuğrul, 2017: 622). Özellikle Siyonizmin Müslümanları "sadece ibadet eden birer köle olarak görmek istediğini” öne süren Erbakan (2017: 30), Siyonizmin en çok cihattan korktuğunu belirterek Müslüman toplumların birleşerek Siyonizme karşı cihat etmesi gerektiğini belirtmektedir. Burada cihat fikrine sahip olması Müslüman Kardeşler gibi İslami hareketlerle örtüştüğü noktalardan biri olmaktadır.

Bu noktada, hem Müslüman Kardeşler hem de Milli Görüş’ün Sünni temelli birer hareket oldukları ve bu yönleri ile İran'ın öncülük ettiği Şii gelenekten ayrıldıklarını belirtmek gereklidir. Her iki yaklaşım türünün de İslam inancının sekülerleşmesine karşı olduğu bu yargılardan anlaşılabilmektedir. Toplumun İslam inancını bireysel bir şekilde yaşamayıp toplumsal anlamda bir İslam şuuru ile hareket ederek refaha ulaşabileceği öne sürülmektedir.

Müslüman Kardeşler'in örgütsel programı hem gelenekselci hem de yenilikçi denilebilecek tarzda bir programd. Misır'daki sorunların ve hem toplumsal hem de siyasal olarak yenilenmesinin çözümü için İslam inancının toplumda ve siyasal alanda etkin hale gelmesini istemesi anlamında gelenekçidir. Fakat aynı zamanda, İslami değerlerle donanmış bir toplumun çağın gerektirdiği teknolojik gelişmelerden de mahrum kalmadan bu gelişmelere ayak uydurması gerektiğini öne sürmekte ve bu anlamda yenilikçi bir profil sergilemektedir (Cleveland, 2004: 224). Müslüman Kardeşler, bu anlamda gelenek ve yeniliklerin bir arada harmanlanabileceği bir toplum ideali ile farklı bir perspektif çizmiştir.

Türkiye'de ortaya çıkan İslamcı politik hareketlerin başında gelen Millî Görüş hareketinin ise önemli bir özelliği, Batı karşıtlığı düşüncesine sahipken aynı zamanda Batı kökenli olan demokrasi ve benzeri değerlere ayak uydurmaya çalışmasıdır (Heper, 2011: 379). Bu tavır, hareketin Orta Doğu toplumlarındaki diğer İslami kesimlerden kısmen farklı olduğunu göstermektedir. Millî Görüş hareketinin Batı karşıtllğ düşüncesinin somutlaştı̆̆ örneklerden biri Avrupa Birliği (AB) üyeliği karşıtı söylemleridir. Erbakan (2017: 217), AB üyeliğinin Türkiye'yi Batıya tamamen bağımlı hale getirecek olan bir adım olduğunu ve bunun sonucunda Türkiye'nin İsrail'in bir vilayetinden farkının kalmayacağını öne sürmektedir. Bu radikal yaklaşımlar daha sonra değişime uğrasa da temelde güçlü bir kesim bu yaklaşımı sürdürmektedir.

Müslüman Kardeşler aydınlanma anlamında yenilikçi bir profil sergilemekte ve bu anlamda sadece gelenekselleşmiş metotlara bağlı kalmamakta ve yeni fikirlere de kapı aralamaktadır. Aynı şekilde Millî Görüş hareketi de her ne kadar Batı karşıtı bir görünüm sergilese de toplumun ilerlemesine katlı sağlayacak olan ve Batı medeniyetinin ürünü olan demokrasi ve benzeri uygulamaları araçsal biçimde bile olsa kabul ederek kullanmaktadır.

Sosyal İnşacı yaklaşıma göre, yapıların birbirlerini dost veya düşman olarak algılamaları veya birbirlerine karşı tutumları taşıdıkları norm ve düşünce faktörlerinin birbirlerine ne derecede benzerlik veya farklılık gösterdiğiyle ilgilidir (Ateş, 2008: 227). İki yapı arasında bu faktörlerin örtüşmesi veya benzerlik göstermesi iş birliği kurmalarını kolaylaştırmaktadır. Bu anlamda Müslüman Kardeşler ve Millî Görüş hareketinin buraya dek değinildiği gibi taşıdıkları benzer düşünceler ve ortaklaştıkları noktalar, aralarında dostane bir ilişkinin kurulmasına olanak sağlamaktadır. 
Küçük’e (2014: 312) göre, bir düşüncenin veya düşünce unsurunun iki aktör arasında ilişki inşa edebilmesi için iki taraflı bir etkisinin olması gereklidir. Aynı düşünce her iki aktör tarafindan da benimsenmeli ve bağlllık teşkil etmelidir Müslüman Kardeşler ve Millî Görüş hareketinin ortaklaştıkları ve ön plana çıkardıkları İslam inancı faktörü, sosyal inşacı yaklaşımın öne sürdügü bu gerekliliği karşılamaktadır. Hem Müslüman Kardeşler'in hem de Millî Görüş hareketinin amaçlarını İslam inancına hizmet çerçevesinde belirlemeleri, aralarında önemli bir düşünce ortaklığı olduğunu göstermektedir.

Görüldüğg̈ üzere Müslüman Kardeşler ve Millî Görüş hareketi bire bir örtüşen hareketler olmasa da birçok noktada benzerlik göstermektedirler. AK Parti her ne kadar sadece "Milli Görüş" kimliği ile tanımlanamasa da kendisinin, kurucularının ve liderinin siyasi ve şahsi geçmişinde dolayısıyla kimliklerinde, önemli bir yer tutan bu ideolojinin politikalarını ve davranışlarını etkilediği aşikârdır. Dolayısı ile AK Parti ve Mursi iktidarları paylaştıkları bu kimlik çerçevesinde iyi ilişkiler kurabilmişlerdir. Her iki hareketin devlet iktidarını elinde bulundurma gücüne sahip olması ve birbirleri ile doğrudan ilişki içerisine girebilmesi ise Orta Doğu bölgesinde yaşanan Arap Baharı sürecinde mümkün hale gelmiştir. Türkiye ve Mısır ilişkilerinin belli bir dönemde sahip oldukları kimlik üzerinden açıklandığı bu makalede, o dönem sahip oldukları kimlik yapılarını ve genel olarak siyasi anlayışlarını anlamak gerekmektedir. Burada kimlik yapıları ortaya konulan Müslüman Kardeşler ve Millî Görüş hareketlerinden etkilenen Ak Parti ve Mursi'’nin bu kimlik çerçevesinde kurdukları ilişkiler bir sonraki bölümde ele alınarak kimliğin Türkiye ile Mısır arasındaki ilişkileri ne şekilde inşa ettiği açıklanacaktır.

\subsection{Adalet ve Kalkınma Partisi Döneminde Değişen Dış Politika Anlayışı ve Orta Doğu Politikası}

Türkiye'de 2002 yılında yapılan seçimle yeni kurulmuş olmasına rağmen tek başına iktidar olan Adalet ve Kalkınma Partisi, Türkiye için siyasi, ekonomik ve ticari anlamda önemli bir süreci başlatmıştır. Türkiye'de bu dönemde küreselleşme olgusuna ayak uydurarak yeni bir dış politika süreci belirlerken Orta Doğu bölgesine ise ayrıcalıklı bir bakış açısıyla farklı bir önem yüklemektedir (Özdemir, 2018: 167). Bu anlamda Türkiye'nin dış politikasını açıklamak için her ne kadar farklı yaklaşımlar öne sürülse de Orta Doğu bölgesi ile olan tarihi bağlarına bakıldığı zaman inşacı yaklaşım daha açıklayıcı bir hale gelmektedir. Adalet ve Kalkınma Partisi iktidara geldikten sonra bölgesel ve küresel anlamda uyum sağlayabildiği sürece Orta Doğu ülkeleri ile tarihi geçmişinden ve stratejik çıkarlarından dolayı yakın ilişkiler kurma vizyonu belirlemiştir (Özkoç, 2017: 83). Burada Adalet ve Kalkınma Partisinin bu vizyonu belirlemesinde Orta Doğu ülkeleri ile sadece coğrafi yakınlık değil geçmişte paylaşılan ortak tarih ve ortak değerler de etkili olmaktadır.

Maddi faktörlerin yanı sıra, en az onlar kadar önemli gördüğü sosyal faktörler üzerinde de duran Wendt (2012: 184), siyasi eylemleri önemli şekilde etkilediğini düşündüğü kimliği ön plana çıkarmış, uluslararası ilişkiler aktörlerinin birbirleri ve sistem ile girdikleri karşlıklı ilişkinin bir sonucu olarak tanımlamıştır. Wendt'e göre; aktörler içinde bulundukları ve sahip oldukları sosyal yapıya göre kendilerine bir kimlik belirlerken bu kimliğe göre çıkarını belirler ve bu çıkarına göre politika oluşturur. Burada Türkiye'nin tarihi geçmişinde Orta Doğu bölgesi ile paylaştığı tarihi süreç ve o süreçte ortaklaştığı norm ve değerler çerçevesinde kendisini Orta Doğu ile ortak bir kimliğe sahip görüp ilişkileri o yönde kurmaya çalıştığı görülmektedir.

Adalet ve Kalkınma Partisi döneminde Türkiye Orta Doğu'ya öncelik verse de aynı zamanda geniş bir dış politika vizyonu belirleyerek bu vizyon ile başta Avrupa Birliği olmak üzere diğer aktörlerle de diplomatik ve ekonomik anlamda ilişkileri geliştirmeye çalışmıştır. Batı medeniyetinin önemli bir eseri olan demokrasi kavramını İslam değerleri ile uyumlaştırabilmiş ve bu anlamda İslam kimliğini korurken Batı dünyası ile geliştirmeye çalıştığı ilişkiler ile aynı zamanda Batı kimliğine de sahip olduğunu ön plana çıkarmıştır (Heper, 2011: 390). Buradan da anlaşılacağ üzere bu dönemde Türkiye bir değil birden çok kimlik çerçevesinde çıarlarını belirlemiş ve ona göre ilişkilerini geliştirmiştir.

Bir devletin birden çok kimliğe sahip olabileceği sosyal inşacı yaklaşımının öne sürdüğü varsayımlardan biridir. Wendt'e (2012: 287) göre her aktör birden fazla kimliğe sahiptir ve sahip olduğu her kimlik türü aktörün davranışlarını şekillendirmede bir misyona sahiptir. Aktörlerin sahip 
olduğu kimlik sonucunda belirlenen ilgileri de karşılaştıkları duruma göre birbirlerine baskın gelebilmektedirler. Burada tehdit unsuru önemli bir etkendir. Hangi kimlik daha çok tehdit altındaysa veya hangi kimliğin gerektirdiği çıkar daha öncelikli ise devletler o kimliği ön plana çıkartarak diğer kimlikleri ikinci plana itmektedir. Burada Türkiye'nin birden çok kimliğe sahip olması aynı zamanda birden çok çıkara sahip olduğu anlamına gelmektedir.

Türkiye'nin dış politikası uzunca bir süre Ak Parti İktidarı döneminde parti içerisinde dış politika yapımına yönelik birçok konumda yer alan Ahmet Davutoğlu tarafından şekillendirilmiştir. Davutoğlu "Komşularla Sifir Sorun" ilkesi çerçevesinde bir diş politika vizyonu belirlemiş ve komşularla girilen iyi ilişkilerin Türkiye'nin güvenlik endişelerini azaltacağını öne sürmüştür. Aynı zamanda Türkiye'nin Orta Doğu'da NATO'nun bir üyesi olarak değil bölgesel bir aktör olarak hareket etmesi gerektiğini vurgulamıștır (Davutoğlu, 2010: 398). Davutoğlu'nun bu düşüncelerinden Türkiye'nin bölgeye yönelik yeni bir kimlik çerçevesinde baktığı anlaşılmaktadır.

Davutoğlu'na göre Türkiye'nin daha önceki dönemlerde dış politikada başarısız olmasının sebebi yönetimin dış siyasette İslam kültürü ve kimliğini terk etmesi sebebi ile Osmanlı'nın birer parçası olarak kalan devletlerden uzaklaşmasıdır. Türkiye'nin bölgesel anlamda bir güç sahibi olmasının yolu çoğunluğu Müslüman kimliğe sahip olan Orta Doğu devletleri ile iyi ilişkiler kurmaktır (Davutoğlu, 2010: 70). Davutoğlu'na göre Türkiye'nin Ak Parti dönemine kadar uygulamış olduğu dış politika, geleneklerden ve komşulardan uzaklaşma politikasıdır. Bunun aşılması için bürokratlar arası ilişkiden çok toplumların paylaştığı ve onları yakınlaştıran olgular üzerinden ilişki kurulmalıdır (Balcı, 2013: 158). Davutoğlu'nun burada toplumun paylaştığı değerleri göz önünde bulundurması Türk Dış Politikasının inşacı bir perspektifle yapıldığını göstermektedir.

Sosyal inşacı yaklaşım iki ana önermeyi temel alır. Birincisi, insanlar tarafından sosyal olarak birliktelikler oluşturulmaktadır ve bu birliktelikler maddi unsurlarla değil paylaşılan düşüncelerle kurulur. İkincisi, amaçlı aktörler olarak kabul edilen devletler de kimlik ve çıkarlarını esas olarak insanların paylaştığı bu düşünceler ile şekillendirmektedir (Özev, 2013: 486). Türkiye'nin yeni dış politika vizyonunun toplumların sosyal değerlerine yönelmesi bu anlamda açılanabilmektedir.

Arap Baharı sürecinin başlaması ve uzun bir dönem boyunca otoriter rejimlerle yönetilen Orta Doğu bölgesinde, kalabalık halk kitleleri sokaklara dökülüp demokrasi talep ederken ortaya çıkan tartışmalardan biri de İslam inancı ilkelerinin ön planda olduğu bu toplumların demokrasiyi İslam inancı ile ne şekilde uyumlu hale getirebileceğidir. Bu tartışmalar sürerken Türkiye, Müslüman kimliğe sahip demokratik bir ülke olması sebebi ile bu ülkelere rol model olabileceği amacı ile bu demokratikleşme hareketlerini yakından takip etmiş ve gerektiğinde müdahalede bulunmuştur (Özkoç, 2017: 81). Davutoğlu, Türkiye'nin kıtalar arası bir köprü olduğu gibi medeniyetler arasında da köprü görevi gördügünü iddia etmektedir. Bu durumda kendisine köprü olma rolü biçilen devlet veya toplumların sadece bir geçiş veya bileşim noktası olmaktan çok, bu kültürel unsurları taşıma işlevini bizzat kendileri gerçekleştirerek üzerinde bulundukları konumu önemli hale getirebilmelidirler (Davutoğlu, 2010: 92). Burada Türkiye'nin Orta Doğu devletlerine rol model olma amacinın, bulunduğu konum ve özellikleri değerlendirebilme isteğinden kaynaklandığı görülmektedir.

Türkiye'nin Orta Doğu'ya bu şekilde yaklaşımı, Orta Doğu ile kolektif kimliğe sahip olma ya da kolektif kimlik oluşturma isteğinden kaynaklanmaktadır. Alexander Wendt'e göre bir devletin başka bir devlete sosyal değerler çerçevesinde dost algısıyla yaklaşması kolektif kimlik oluşturma ihtimalinin ve isteğinin en belirgin amaç ve göstergesidir. Aynı şekilde bir devletin başka bir devlete karşı toplum yanlısı duruşu kolektif kimlik yaratma amacı olduğu gibi bu davranış var olan kolektif kimliğin de bir sonucudur (Wendt, 2012: 416). Burada Wendt'in kolektif kimliğe yönelik açıkladığ1 her iki görüşün de Türkiye'nin politikası açısından geçerli olduğu söylenebilmektedir. Tarihi ve kültürel bağlara bakıldığı zaman Türkiye'nin Orta Doğu toplumu yanlısı duruşu Orta Doğu ile var olan kolektif kimliğin sonucu olarak görülebileceği gibi, Türkiye'nin değişim yaşayan bu toplumlara rol model olma açısından kolektif kimlik oluşturma amacı ve isteği taşıdığı da görülebilmektedir.

Davutoğlu'na göre bölgesel düzenin yeniden kurulduğu bir süreçte Türkiye'nin Arap ülkeleri ile kuracağı ilişki sadece ikili bir çıkar kazanımına değil aynı zamanda bölgenin ihtiyaç duyduğu ve kurulması gereken bölgesel barışa da hizmet etmesi açısından önem taşımaktadır. Ama böylesi bir ilişkinin kurulabilmesi için bütün tarafların ortaklaştıkları norm ve değerleri göz önüne alarak "ortak 
bölge kaderi” bilincine sahip olmaları gerektiğini dile getiren Davutoğlu (2010: 414), ancak bu şekilde bölge dış1 aktörlerin yönlendirmesine engel olunabileceğini ve ilişkilere sağlam bir zemin oluşturulabileceğini öne sürmektedir. Wendt'e (2012: 425) göre, kendilerini benzerlikler üzerinden kurulan bir grubun mensubu olarak gören aktörlerin, varlıkları, gelecekleri, zindelikleri ve refahları grubun kaderine bağlı ise bu aktörler ortak bir kaderi paylaşırlar. Aynı şekilde kendilerini paylaştıkları benzerlikler üzerinden sınıflandıran bu aktörler grup içerisinde homojen davranarak kolektif kimlik oluştururlar (Wendt, 2012: 430). Davutoğlu'ndan da anlaş1ldığı üzere Türkiye Orta Doğu'ya yönelik bir grup bilincine sahip ve kendisinin de içerisinde bulunduğu bu grubun ortak bir kaderi paylaştığını düşünmektedir.

Müslüman Kardeşler ve Milli Görüş hareketi karşılaştırıldığında, bu iki siyasi hareket birebir örtüşen hareketler olmasa da birçok noktada ortak ve benzer anlayışlara sahiptirler. Sahip oldukları bu ortaklık ve benzerlikler ise uygun şartlar ve koşullar ortaya çıktı̆̆ında iki devletin birbirleri ile uyumlu politikalar yaparak iyi bir ilişki kurmalarına zemin hazırlamaktadır. Türkiye'nin incelenen dönemdeki dış politikasına bakıldığında da kimlik eksenli bir dış politika anlayışına sahip olduğu görülmektedir. Bir sonraki bölümde ise bu dönemde ise bu kimlik benzerliğinin iki devlet ilişkisine ne şekilde etki ettiği açıklanacaktır.

\section{MUHAMMED MURSI İKTIDARI VE DEĞISSEN TÜRKIYYE-MISIR İLIŞKIILERI}

Müslüman Kardeşler Arap Baharı sürecinde Mısır'da gerçekleşen meclis seçimlerinde \%47 oy alarak mecliste önemli bir başarı elde etmiştir. Daha sonra gerçekleşen cumhurbaşkanlığı seçimleri için de Muhammed Mursi'yi aday göstererek seçimlere gireceğini ilan etmiştir (Kılavuz vd., 2012: 39). 24 Haziran'da gerçekleşen Cumhurbaşkanlığı seçimlerinin son turunda Müslüman Kardeşlerin adayı Muhammed Mursi, \%51,3 oy alarak Mısır'da cumhurbaşkanlığı koltuğuna oturmuştur (Pargeter, 2010: 197). Bununla beraber Müslüman Kardeşler eylemler sırasında elde ettiği başarıyı seçim döneminde de göstererek resmi olarak girdiği ilk seçimlerde Mısır 'da iktidara gelmiştir.

Mısır'da Müslüman Kardeşlerin iktidara gelmesi Türkiye iktidarında bulunan Adalet ve Kalkınma Partisi yönetimi tarafından sevinçle karşılanmış ve Türkiye, Muhammed Mursi’yi tebrik eden ilk ülkelerden biri olmuştur. Türkiye'nin bu yaklaşımı, ilişkilerin yeni bir boyuta geçeceğinin habercisi olmaktadır.

Brown ve Ainley (2013: 63), içinde bulunduğumuz sosyal dünyanın insanlar tarafından inşa edildiğini belirterek uluslararası ilişkiler alanını insanlar arası ilişkilerin daha geniş bir perspektifi olarak görmektedir. Bu durumda devletlerin dost ve düşman algıları da sabit kalmamakta ve zamanla değişebilmektedir. Burada iki ülkenin birbirlerine karşı ortaya koyduğu bu tavırda bir önceki bölümde anlatılan Müslüman Kardeşler ve Millî Görüş hareketinin düşünsel benzerliği etkili olmaktadır. Türkiye ile Mısır arasında o döneme kadar bu tür tepkinin yaşanmamış olması ve bu iki siyasi düşüncenin birbirlerine benzerlikleri sebebi ile iki devlet arasında bu tür bir etkileşimin yaşanması burada değinilen sosyal inşacı yaklaşımın önermelerini doğrulamaktadır.

Mısır'da Mübarek rejiminden sonra Müslüman Kardeşler seçimle iktidara geldiğinde Mısır'a ilk resmi ziyareti Türkiye Cumhurbaşkanı Abdullah Gül yapmıştır. Gül, Muhammed Mursi ile görüşerek seçim zaferinden dolayı tebriklerini iletmiştir (Alkan, 2019: 65). Sosyal inşacı yaklaşıma göre dil karşılıklı etkileşim için önemli bir araçtır. Sosyal dünya ve toplumsal anlam taşıyan davranışlar dilin kullanılmasıyla kurulur ve şekillenir (Küçük, 2014: 353). Dil ve çeşitli araçlar vesilesiyle birbirleri ile etkileşime giren devletler, sadece istediklerini almaya çalışmamakta aynı zamanda kendi benliklerini oluşturan temel değer ve anlayışlarını da sürdürmeye çalışmaktadırlar (Wendt, 2012: 200). Burada Abdullah Gül'ün yaptığı ziyaret iki ülkenin bu süreçte birbirlerine bakışını ve birbirlerine yaklaşımının ortaya koyan önemli bir sosyal davranıştır.

Başbakan Recep Tayyip Erdoğan 13 Eylül 2011 tarihinde olayların durulduğu sırada Mısır'a bir ziyaret gerçekleştirmiş ve bu ziyaretinde ihtilalden zaferle çıkmış bir konumda bulunan kitleler tarafından coşku ve sevinçle karşılanmıştır. 17 Kasım 2012 tarihinde Mısır Cumhurbaşkanı Muhammed Mursi, Recep Tayyip Erdoğan'ın daveti ile Adalet ve Kalkınma Partisinin kongresine katılmış ve Tahrir devrimi sürecinde kendilerine destek verdiği için Türkiye'ye teşekkür etmiştir. Daha sonra Abdullah Gül, Recep Tayyip Erdoğan ve Muhammed Mursi'nin katılımı ile Türk-Mısır iş forumu düzenlenmiştir. Bu forum sırasında iki ülke arasında 2 milyar dolarlık kredi anlaşması ve ek 
ticaret anlaşmaları yapılarak önemli bir ticaret ve iş birliği adımı atılmıştır (Alkan, 2019: 66). Bu iki ülke arasında atılan bu adımlar iki aktörün sosyal ve normatif unsurlar sebebi ile yakınlaşmasının maddi yakınlaşmayı ve iş birliğini de doğurduğunu göstermektedir.

Devletler maddi yapılardan çok ortak düşünce yapılarıyla birbirlerine bağlanmakta ve iş birliği kurmaktadır. Devletler sahip oldukları inanç, değer ve benzeri ortak düşünce yapıları sayesinde ittifak kurabilmekte ve aynı yönde davranış sergilemektedirler (Kolasi, 2018: 15). Bu dönemde Türkiye ve Mısır'ın sahip oldukları benzer kimlik ve paylaştıkları ortak değerler sebebi ile iş birliği yapmaları kolaylaşmaktadır.

Kasım 2012 tarihinde Başbakan Recep Tayyip Erdoğan Türk iş adamları ile beraber Mısır'a resmi bir ziyaret gerçekleștirmiș ve bu ziyaret çerçevesinde iki ülke arasında önemli bir iș birliği adımı atılarak 27 protokol ve iş birliği anlaşmasına imza atılmıştır (Balcı, 2013: 310). Bu gelişmelerin sonucunda iki ülke arasında 2011 yılında 3,2 Milyar olan ticaret hacmi 2012 yılında ikiye katlanmıştır. Bununla beraber iki ülke arasında ilişki anlamında somut adımlar atılmaya başlanmış ve daha sonra küçük kapsamlı da olsa iki ülke arasında ilk kez Akdeniz'de ortak askeri tatbikat düzenlenmiş ve askeri anlamda bazı anlaşmalara imza atılmıştır (Demirtaş, 2012). İki ülkenin beraber askeri tatbikat düzenlemesi, bu iki ülkenin birbirlerinin gücünden doğrudan bir tehdit algılamadıklarını ortaya koymaktadır. Bu da aslında yapılan anlaşma ve iş birliği zemininin güçlü olduğu veya güçlendirilmek istediğini göstermektedir.

Sosyal inşacı yaklaşıma göre, kimlik yapılarına göre birbirlerinin davranışlarını tahmin edebilen devletler mahkûmun ikilemi oyununu görece aşarak daha istikrarlı ilişkiler kurabilmektedirler (Nugroho, 2008: 93). Bir ülke gücünü maksimize etmeye çalıştı̆̆ında coğrafik olarak kendisine aynı yakınlıkta olan iki devlet buna farklı tepkiler verebilmektedir. $\mathrm{Bu}$ da bu devletlerin bu güç maksimizasyonundan ne anladıkları ile açıklanabilecek bir şeydir. Kimlik, ideolojilerin mantığı ve kurulu dostluk ve düşmanlık yapıları bu gücün ne şekilde anlamlandırılması gerektiğini belirlemektedir.

Burada Türkiye ve Mısır'ın sahip oldukları ortak veya benzer kimlik, iki devletin birbirlerinin güç ve kapasitelerinden tehdit algılamamalarını sağlamaktadır. Birbirlerinden tehdit algılamayan iki devlet ortak askeri tatbikata varacak kadar iş birliğini ilerletebilmektedirler. Uzun yıllar boyunca Akdeniz coğrafyasındaki askeri kapasiteleri birbirlerine yakın iki rakip olarak görülen Türkiye ve Mısır'ın bu rekabetten vazgeçip iş birliğine yönelmelerine sebep olan en önemli etkenlerden bir iki ülkenin paylaştıkları sosyal değerler çerçevesinde ortak çıkar tanımlaması yapmalarıdır.

Wendt'e (2012: 430) göre homojenlik, devletlerin birbirlerine benzerliklerinin ön plana çıktığ 1 ve bu benzerlikler üzerinden çıkarlarının daha kolay uyumlu hale gelebildiği durumda kolektif kimlik oluşumuna etki eden bir unsurdur. Burada devletlerin rejim yapılarının benzer olması gibi özellikler homojenleşmenin önemli etkenlerinden biridir. Burada, bu dönemde Mısır ile Türkiye'nin diş politikada birbirlerine benzer bir anlayış içerisinde oldukları görülmektedir. Benzer anlayışla dış politika yapmaları ise her iki devletin çıkarlarının uyumlu hale gelmesini ve daha kolay bir şekilde iş birliği yapmalarını sağlamaktadır.

Bu gelişmelerin sonunda Türkiye ile Mısır ilişskileri önemli derecede iyileşmiş ve iki devlet birçok konuda fikir birliği yapmaya başlamıştır. Örneğin Suriye'de başlayan ve dozu gittikçe artan çatışmaların nasıl çözüleceğine dair iki ülke sürekli farklı düzeylerde görüşmeler yaparak çözüme yönelik ortak yaklaşımda bulunma çabası göstermişlerdir (Nouhy, 2017: 77). Mısır ve Türkiye bu dönemde ilişkilerinin altın çağını yaşamış ve her iki ülke Orta Doğu bölgesinde ortak hareket ederek Akdeniz'de önemli iki müttefik haline gelmiş ve dikkatleri üzerlerine çekmiştir. Her iki ülkenin de stratejik olarak önemli bir potansiyele sahip olması ve bu denli bir ilişki kurması Orta Doğu'da yeni ve güçlü bir Sünni güç bloğu oluştuğu tartışmalarına yol açmıştır (Arslantaş, 2013: 129). Misır ve Türkiye, uzun yıllar boyunca özellikle Akdeniz bölgesinde rekabet halinde iken bu dönemde rekabeti ortadan kaldıran önemli iki müttefik haline gelmişlerdir.

Küçük’e (2014: 326) göre uygun sosyal ve düşünsel şartlar ortaya çıktığında iki aktör arasında ilişkiler kurulabilir veya bozulabilir bunun gerçekleşmesi belli süreç sonrasında ortaya çıkan konjonktürden kaynaklanmaktadır. Türkiye ve Mısır arasındaki ilişkilerin değişimi öne sürülen bu yargı aracılığı ile açıklanabilmektedir. İki ülke arasında uzun bir tarihten kaynaklanan ortak bir kimlik 
paylaşımı bulunmaktadır (Baş, 2015: 32). Bu ortak kimlikten kaynaklı ilişkilerin olumlu gelişme göstermesi ise belli bir uygun ortam veya ortak kimliğin niteliğini ortaya çıkaracak düşünsel değer paylaşımının ortaya çıkmasını beklemiştir. İki ülkede aynı kimliğin benzer yönlerini referans alan iktidarların başa gelmesi ilişkilerin hızlı bir şekilde gelişmesini sağlamıştır.

Reus- Smit'e (2014: 294) göre devletler nasıl sosyal etkenler ve düşünsel değerlerin paylaşımı ve aynı kimliğe mensup oldukları için ilişkilerinde belli bir inşa süreci yaşayıp olumlu ilişkiler geliştiriyorlarsa aynı zamanda bu sosyal etkenlerin birbirine uzak olması sebebi ile de ilişkilerinde bozulma veya kopmalar yaşanabilmektedir. Buradan hareketle Türkiye ve Mısır arasında ilişkiler bir dönem önemli ölçüde olumlu seyrederken ve iki ülke arasında kısa sürede ciddi bir yakınlaşma ve çıkar ortaklığı gerçekleşmişken Mısır'da Müslüman Kardeşler yönetiminin askeri darbe ile indirilmesi sonrasında ilişkilerin değişen seyrinin açıklanabilmesi de mümkündür.

\subsection{Mursi İktidarının Devrilmesi ve ilişkilerin Kopması}

Mısır'da yeni bir demokratik düzen oturtulmaya çalış1lırken, halkın beklentileri karşılanamamış ve 3 Temmuz 2013'te General Fettah El Sisi önderliğinde gerçekleşen bir darbe ile Muhammed Mursi'nin iktidardan indirilmesi ile Mısır ve Türkiye arasındaki ilişkiler de yeni bir boyuta geçmiştir. Mursi'nin askeri darbe ile iktidardan indirilmesine Türkiye sert tepki göstermiş ve iki ülke arasında ilişkiler kopmuş ve bir süredir iyi giden ikili ilişkiler diplomatik krize dönüşmüştür (Akgün ve Gündoğar, 2014: 5). Burada iki ülke arasında ortaya çıkan yönetim anlayışı farkının ilişkileri doğrudan etkilediği görülmektedir.

İki devlet arasında yaşanan bu gelişmeler ile iki devlet karşılıklı olarak büyükelçilerini geri çekmiş, bir süredir en iyi şekli ile büyükelçi seviyesinde seyreden ilişkiler maslahatgüzar seviyesine indirilmiştir (Özkoç, 2017: 94). Bu yaşananlar sonucunda Davutoğlu Mısır'daki darbe ile ilgili şunları söylemiştir, "Mısır'daki ilişkilerimiz açısından en önemli şey meşruiyet meselesi. Bu darbe ile Mısır'da demokratik seçimler sonucunda en fazla oy almış bir siyasi hareket gayri meşru ilan edilmeye çalışıllyyor. Yani bir anlamda bizim yaşadığımız 28 Şubat darbesine çok benziyor, bizim bu darbeyi yapanlar ile ayn ilişkiyi sürdürmemiz kabul edilemez" (Hayatsever, 2015). Burada yaşanan gerginliklerden sonra Davutoğlu'nun bu söylemi de gösteriyor ki Türkiye'nin tavrı Mısır'da gerçekleşen bu sosyal olayla ilgilidir. Aynı zamanda başa gelen iktidarı düşünsel ve eylemsel olarak kendisinden çok farklı gördüğü için ilişkilerin bu şekilde tıkandığını iddia etmektedir. Aynı şekilde Davutoğlu'nun yaşanan bu darbeyi 28 Şubat süreci ile benzer bir şekilde algılaması da iki aktörün benzer süreçlerden geçmesinin kurdukları ilişkiyi etkilediğini göstermektedir

Aynı zamanda Türkiye'deki iktidar Mısır'da gerçekleşen darbeye diğer ülkelerin sessiz kaldığını öne sürerek kendisinin Mısır ile ilişkileri kesmesini yeterli bulmamış ve diğer devletlerin de ilişkileri kesmesini istemiş̧ir (Hayatsever, 2015). Böylelikle Türkiye Bu iktidara önemli ölçüde karş1 olduğunu ortaya koymuş ve ilişkilerin kesilmesinin iktidarlar arası görüş farklılıklarından kaynaklandığı görüşü güç kazanmıştır.

Türkiye ile Mısır arasında bu dönemde yaşanan ilişkilerdeki değişimi açıklamak için yukarıda değindiğimiz sosyal inşacı yaklaşımın öne sürdüğü olgular açısından değerlendirmek açıklayıcı bir yöntem olmaktadır. Çünkü ilişkiler Mısır'da iktidara gelen Müslüman Kardeşler yönetiminin sosyal ve düşünsel olarak Türkiye'deki iktidar partisine yakın olması ve bu sayede belli değerler çerçevesinde ortak bir kimlik oluşması sayesinde gelişmiştir ve yine iktidar değişikliğinden sonra iki ülke iktidarı arasındaki görüş farklılı̆̆ 1 ve ortak değerlerin ortadan kalkması sonucunda herhangi kimliksel yakınlık ve ortak değerin kalmaması sonucunda ilişkiler kopmuştur.

Normatif ve düşünsel yapılar iki aktör arasındaki kimlikleri ve çıkarları şekillendirir ve ilişkiler bu yeni şekillendirme çerçevesinde seyreder (Reus-Smit, 2014: 295). Wendt'e (1999: 412) göre ortak değerleri paylaşan aktörler bir kolektif kimlik oluşturma çabasına girerler ve bu amaçla ilişkiler belli bir düzeyde gelişme gösterirler. Türkiye ve Mısır arasında inanç temelli bir yakınlık ve tarihsel bir ortak yaşanmışlıktan (Baş, 2015: 92) kaynaklanan bir birliktelik potansiyeli vardır. Mısır'da Müslüman Kardeşlerin başa gelmesinden sonra iki iktidar arasındaki görüş benzerliğinden dolayı bu ortak inançsal ve tarihsel arka plan daha görünür hale gelmiştir ve kolektif kimlik kurma isteği ile iki devlet arasında ilişkiler hızlı bir şekilde olumlu yönde gelişmiştir denilebilmektedir. 


\section{TARTISSMA VE SONUÇ}

Uluslararası ilişkiler disiplini içerisinde kimliğin nasıl bir konumda olduğunu ve devletler arası ilişkileri açıklamakta nasıl bir role sahip olduğunun Mursi dönemi Türkiye- Mısır ilişkileri ekseninde açıklandığı bu çalışmada devletlerin birbirlerine karşı konumlarını sahip oldukları kimliğe göre belirledikleri tezi öne sürülmüştür. Devletlerin eylemlerinin, çıkarlarının bir sonucu olarak meydana geldiğini ve çıkarlarının ise kimliklerine göre belirlendiği ve devletlerin kimliğinin ise sürekli bir inşa sürecinde olduğu varsayımı dikkate alınmıştır. Devletlerin birbirleri ile girdikleri ilişkilerin dış politikayı ve uluslararası ilişkileri oluşturduğu varsayımı bu çalışmada kimlik kavramının merkezi bir konumda ele alınmasını gerekli kılmıştır.

Mursi dönemi Türkiye-Mısır ilişkilerine bakıldığı zaman iki devlet ilişkisinin bu dönemde kimliklerinin birbirleri ile uyumu üzerinden gerçekleştiği görülmektedir. Bu dönemde benzer kimlik yapılarına sahip olan Müslüman Kardeşler ve Millî Görüş hareketinden gelen Adalet ve Kalkınma Partisinin, kimlikler üzerinden birbirleri ile uyumlu çıkarlar belirledikleri ve bu yönde ilişki kurdukları anlaşılmaktadır. Müslüman Kardeşler ve Millî Görüş düşüncesinin iktidarda olması Mısır ile Türkiye'nin ortaklaştıkları kültür, inanç, tarihsel birliktelik temelli bir müttefik ilişkisi kurulmasını sağlamıştır. Çünkü hem Müslüman Kardeşler hem de Millî Görüş hareketi bu değerleri içselleştirmiş ve siyasal anlayışlarında önemli bir konuma oturtmuşlardır. Buradan hareketle sosyal inşacı yaklaşımın iddia ettiği gibi kimlik ve sosyal değerler bu iki devletin politikalarını şekillendirmiştir. Ortak olan bu değerler sonucunda iki devlet önceki dönemlerine göre daha iyi bir ilişki kurmuş ve benzer olan kimliklerinin gerektirdiği şekilde çıkar belirlemesi yaparak müttefik iki devlet haline gelmişlerdir.

Çalışmanın teorik çerçevesini oluşturan sosyal inşacı yaklaşım, devletlerin kimliklerinin nasıl oluştuğunu, kimlik oluşumunda etkili olan faktörlerin neler olduğunu ve edindikleri bu kimlik sonucunda devletlerin nasıl politika oluşturduğunu açıklamak amacıyla ayrı bir bölüm olarak ele alınmıştır. Öncelikle yaklaşımın temel önermeleri anlatılarak genel olarak uluslararası ilişkiler alanında devlet eylemlerini açılamak için yaklaşımın kurucu düşünürleri başta olmak üzere birçok farklı düşünürün yazıları analiz edilmiştir. Yaklaşımın üzerinde durduğu ve devlet davranışlarını açıklamak için önemli bir unsur olarak gördüğü kimlik ve düşünce faktörleri ayrı başlıklar altında değerlendirilerek anlatılmıştır. Kimlik oluşumu ve inşa süreci anlatılırken kimlik inşasında devletlerin kendi varlıkları dışında etkilendikleri dışsal faktörler ve devlet kimliğinin iç dinamiklerini oluşturan içsel faktörler açıklanmıştır.

Çalışmanın ikinci bölümünde yaklaşımın ortaya koyduğu argümanlar ekseninde Müslüman Kardeşler ve Millî Görüş hareketi karşılaştırmalı bir şekilde ele alınarak anlatılmıştır. Müslüman Kardeşler ve Millî Görüş hareketinin ideolojileri ve siyasal süreçleri göz önünde bulundurulduğunda aralarında farklılıklar olmasına rağmen benzer veya ortaklaştıkları birçok nokta olduğu ve bunun da uygun koşullar meydana geldiğinde iki devlet arasında yeni bir ilişki inşa edebilecek nitelikte olduğu anlaşılmıştır.

Üçüncü bölümde sosyal inşacı yaklaşımın varsayımları ve Müslüman Kardeşler ile Millî Görüş hareketinin ortaya konulan benzerlik ve ortaklıkları ekseninde Mursi dönemi Türkiye-Mısır ilişkileri tezin örnek vakası olarak değerlendirilerek anlatılmıştır. Bu dönemde bölgede gelişen Arap Baharı süreci anlatılarak bu sürecin Mısır'da ne şekilde gerçekleştiği, Müslüman Kardeşlerin bu sürecin bir sonucu olarak iktidara ne şekilde geldiği ve Türkiye'nin buna yönelik tutumu açıklanmıştır. Türkiye'nin bu sürecin başından itibaren bölgeye yönelik dış politikasına bakıldığ 1 zaman bölge toplumu ile var olan sosyal bağlar neticesinde bölge ülkeleri ile ilişkilerinde kimliği ön plana çıkardığı ve bölgedeki çıkarlarını kimliğine göre belirlediği görülmektedir.

Müslüman Kardeşler Mısır'da iktidara geldikten sonra Türkiye ile Mısır arasında ilişkilerin ne şekilde değiştiği ve bunda iki ülkenin iktidar anlayışlarının birbirlerine benzer olmasının ne derecede etkili olduğu açıklanmıştır. İlişkilerin bir önceki dönemlere göre çok farklı bir eksende yürütülmesinde iki devletin o dönemde sahip oldukları kimliğin rolü ve bu benzer kimlik ekseninde nasıl bir ilişki inşa ettikleri anlatılarak ilişkilere yön veren etkenler ortaya konulmuştur. Daha sonra Mursi iktidarının devrilmesi ve Türkiye'nin buna tepkisi sonucunda ilişkilerin önemli ölçüde kopartılmasında benzer iktidar anlayışlarının ortadan kalkması ile ilişkilerin değişebileceği ortaya konulmuştur. Sonuç olarak 
iki devletin bu dönemde birbirlerine yönelik algıları ve bunun sonucunda geliştirilen ikili ilişkilerin sosyal benzerlik ve ortaklıklar sonucunda inşa ettikleri kimlik yapılarından kaynaklandığ 1 görülmektedir.

Etik Beyan: Bu çalışmada "Etik Kurul” izini alınmasını gerektiren bir yöntem kullanılmamıştır.

Yazar Katkı Beyant:1. Yazarın katkı oranı \%50, 2. Yazarın katkı oranı ise \%50'dir.

Çıkar Beyant: Yazarlar arasında çıkar çatışması yoktur.

Ethics Statement: In this study, no method requiring the permission of the "Ethics Committee" was used.

Author Contributions Statement: 1st author's contribution rate 50\%, 2nd author's contribution rate $50 \%$.

Conflict of Interest: There is no conflict of interest among the authors.

\section{KAYNAKÇA}

Akgün, M., \& Gündoğar, S. (2014). Misır-Türkiye ilişkilerinde daha iyi bir geleceğe doğru. TESEV Dergisi Diş Politika Programı content/uploads/rapor_M\%C4\%B1s\%C4\%B1r-Tu\%CC\%88rkiye-ilis\%CC\%A7kilerinde-dahaiyi-bir-geleceg\%CC\%86e-dog\%CC\%86ru.-12-Mart-14.pdf

Akpınar, B. (2015). AKP hükümetlerinin dış politika söylem ve pratiği: İņacı perspektiften bir analiz [Yüksek Lisans Tezi, Yıldız Teknik Üniversitesi] Yükseköğretim Kurulu Tez Merkezi. https://tez.yok.gov.tr/UlusalTezMerkezi/tezSorguSonucYeni.jsp

Alkan, S. (2019). Hüsnü Mübarek dönemi ve Arap Baharı'nda Türkiye-Misır ilişskileri [Yüksek Lisans Tezi, Karadeniz Teknik Üniversitesi] Yükseköğretim Kurulu Tez Merkezi. https://tez.yok.gov.tr/UlusalTezMerkezi/tezSorguSonucYeni.jsp

Arı, T. (2004). Geçmişten günümüze Ortadoğu: Siyaset, savaş ve diplomasi. Alfa Yayıncılık.

Arı, T. (2010). Uluslararası ilişkiler teorileri: Çatışma, hegemonya, iş birliği. MKM Yayınları.

Arslantaş D. (2013). Müslüman Kardeşler ve AKP geleneğinin siyasi analizi: Türkiye modeli neden başarısızlığa uğradı? [Yüksek Lisans Tezi, Orta Doğu Teknik Üniversitesi] Yükseköğretim Kurulu Tez Merkezi. https://tez.yok.gov.tr/UlusalTezMerkezi/tezSorguSonucYeni.jsp

Ateş, D. (2008). Uluslararası ilişkilerde konstrüktivizm: Ortayol yaklaşımının epistemolojik çerçevesi. Sosyal Bilimler Dergisi, 10(1), 213-235. http://hdl.handle.net/11630/3714

Balc1, A. (2013). Türkiye dış politikası: İlkeler, aktörler ve uygulamalar. Etkileşim Yayınları.

Baş, A. (2015). Atatürk dönemi Türkiye-Mısır ilişkileri ve günümüze etkileri. Atatürk Araştırma Merkezi Dergisi, 31(92), 31-76. https://dergipark.org.tr/en/pub/aamd/issue/44030/542411

Benna H. E. (2017). Müslüman Kardeşler teşkilatı. H. H. Yılmaz (Çev.), Özgü Yayınları.

Benna, H. E. (2019). Hatıralarım: Müslüman Kardeşler. B. M. Eryarsoy (Çev.), Beka Yayıncılık.

Brown, C., \& Ainley K. (2013). Understanding internaiıonal relations. Sümer Kitabevi.

Cleveland, W. L. (2004). A history of modern Middle East, Westwiew Press.

Davutoğlu, A. (2010). Stratejik derinlik: Türkiye’nin uluslararası konumu. Küre Yayınları.

Demirtaş, S. (2012, Kasım 15). Türkiye ve Mısır: Yeni bir bölgesel ittifaka doğru. BBC Haber. https://www.bbc.com/turkce/haberler/2012/11/121115_turkey_egypt

Erbakan, N. (2013). Davam: Ne yaptıysam Allah rızası için yaptım. MGV Yayınları.

Erbakan, N. (2017). Adil ekonomik düzen. MGV Yayınları.

Hayatsever, H. (2015, Ağustos 5). Türkiye- Misır ilişsileri neden normalleşemiyor. Sputnik Haber. https://tr.sputniknews.com/columnists/201508051016952244/

Heper, M. (2011). Türkiye'nin siyasal hayatı. Doğan Egmont Yayıncılık. 
Hoffman, M. J. (2010). Norm and social constructivism in international relations. Oxford Research Encyclopedia.

Kaya, S. (2009). Uluslararası ilişkilerde konstrüktivist yaklaşımlar. Ankara Üniversitesi SBF Dergisi, 63(3),

83-111. https://dspace.ankara.edu.tr/xmlui/bitstream/handle/20.500.12575/53055/11653.pdf?sequence= $\underline{1 \& i s A l l o w e d=y}$

Kaya, Ü. İ. (2016). Müslüman Kardeşler teşkilatının ideolojisi ve Mısır siyaseti üzerindeki etkileri. Klrlkkale Üniversitesi Sosyal Bilimler Dergisi, 6(2), 131-151. https://dergipark.org.tr/en/download/article-file/232262

Kiraz, S. (2014). Sosyal inşacı yaklaşımda güvenlik. İçinde E. Çıtak, \& O. Şen (Der.), Uluslararası ilişkilerde güvenlik: Teorik değerlendirmeler. Röle Akademik Yayıncılık.

Kolasi, K. (2018). A meta theoretical critique of the social ontology understanding in international $\begin{array}{lllll}\text { relations. } & \text { Uluslararası Ilişkiler }\end{array}$ https://www.uidergisi.com.tr/yazilar/uluslararasi-iliskilerde-sosyal-ontoloji-kavrayisinin-metateorik-elestirisi

Küçük, M. (2014). Uluslararası ilişkilerde sosyal inşacıllk. İçinde, R. Gözen (Der.), Uluslararası ilişskiler teorileri. İletişim Yayınları.

Levy, R. A. (2014). The idea of jihād and its evolution: Ḥasan al-bannā and the society of the muslim brothers. Die Welt des Islams, 54(2), 139-158. https://doi.org/10.1163/15700607-00542p01

Manaz, A. (2008). Siyasal İslamcılık: Türkiye’de siyasal İslamcılık. IQ Kültür Sanat Yayıncılık.

Nouhy, E. A. A. (2017). Arap baharı sonrası Türkiye’nin Mısır yumuşak gücü [Yüksek Lisans Tezi, Gazi Üniversitesi] Yükseköğretim Kurulu Tez Merkezi. https://tez.yok.gov.tr/UlusalTezMerkezi/tezSorguSonucYeni.jsp

Nugroho, G. (2008). Constructivism and international relations theories. Global \& Strategies, 2(1), 8598. https://citeseerx.ist.psu.edu/viewdoc/download?doi=10.1.1.452.2331\&rep=rep1\&type=pdf

Onuf, N. G. (1998). World of our making: Rules and rule in social theory and international relations. Universty of South Carolina Press.

Özdemir, Ç. (2018). Ak Parti dönemi Türkiye'nin Ortadoğu politikası: Inşacılıktan realizme dönüşüm. SETA Avrupa Çalışmaları. https://www.academia.edu/download/60283528/AK_Parti_Donemi_Turkiyenin_Ortadogu_Polit ikasi_Insaciliktan_Realizme_Donusum20190813-49017-1qbhinf.pdf

Özev, H. M. (2013). Eleştirel teori olarak konstruktivizm. İçinde H. Çomak, \& C. Sancaktar (Der.), Uluslararası ilişkilerde teorik tartışmalar. Beta Yayınları.

Özkoç, Ö. (2017). Türkiye'nin Kuzey Afrika'ya yönelik politikası: Bir modelin çöküşü. Ankara Üniversitesi SBF Dergisi, 72(1), 77-97. https://doi.org/10.1501/SBFder 0000002438

Pargeter, A. (2010). Müslüman Kardeşler: Muhalefetten iktidara. S. Çelik (Çev.), Ayrıntı Yayınları.

Pınar, F. (2015). Hasan El-Benna ve Müslüman Kardeşler. Iğdır Üniversitesi Illahiyat Fakültesi Dergisi, (5), 133-153. https://dergipark.org.tr/en/download/article-file/543079

Reus-Smitt, C., Burchill, S., Linklate, A., Devetak, R., Donelly, J., Nardin, T., Patterson M., \& True, J. (2014). "Konstruktivizm” uluslararası ilişsiler teorileri, Küre Yayınları.

Tuğrul, T. (2017). Milli Görüş Hareketi'nin temel karakterleri. e-Makalat Mezhep Araştırmaları Dergisi, 10(2), 617-657. https://doi.org/10.18403/emakalat.317808

Ülger, U. (2017). Siyasal İslam'ın AB'ye bakış açısı: Milli Görüş Hareketi örneği. Journal of Suleyman Demirel University Institute of Social Sciences, 29(4), 619-632. https://sbedergi.sdu.edu.tr/assets/uploads/sites/343/files/29-sayi-yazi28-30122017.pdf 
Wendt, A. (2012). Uluslararası siyasetin sosyal teorisi. H. Sarı Ertem, \& S. G. Ihlamur Öner (Çev.), Küre Yayınları.

Wendt, A. E. (2013). Anarşi devletler ne anlıyorsa odur: Güç politikalarının sosyal inşası. Uluslararası İlişkiler Dergisi, 10(39), 3-43. https://dergipark.org.tr/en/download/articlefile/540255

Yılmaz, S. (2016). Milli Görüş Hareketi: Toplumsal hareketlerde çerçeve değişimi etkisi. İnsan ve Toplum Bilimleri Araştırmalarl Dergisi, 5(4), 1164-1185. http://www.itobiad.com/en/download/article-file/206404 